\title{
Article \\ Differential Evolution of Farmers' Livelihood Strategies since the 1980s on the Loess Plateau, China
}

\author{
Kongsen $\mathrm{Wu}^{1,2}$, Xinjun Yang ${ }^{1,2, *} \mathbb{C}$, Jian Zhang ${ }^{2}$ and Ziqiao Wang ${ }^{2}$ \\ 1 Shaanxi Key Laboratory of Earth Surface System and Environmental Carrying Capacity, \\ Northwest University, Xi'an 710127, China; wukongsen@stumail.nwu.edu.cn \\ 2 College of Urban and Environmental Sciences, Northwest University, Xi' an 710127, China; \\ zhangjian0726@snnu.edu.cn (J.Z.); wangzq@stumail.nwu.edu.cn (Z.W.) \\ * Correspondence: yangxj@nwu.edu.cn
}

Citation: Wu, K.; Yang, X.; Zhang, J.; Wang, Z. Differential Evolution of Farmers' Livelihood Strategies since the 1980s on the Loess Plateau, China. Land 2022, 11, 157. https://doi.org/ 10.3390/land11020157

Academic Editor: Charlie Shackleton

Received: 28 December 2021

Accepted: 18 January 2022

Published: 19 January 2022

Publisher's Note: MDPI stays neutral with regard to jurisdictional claims in published maps and institutional affiliations.

Copyright: (C) 2022 by the authors. Licensee MDPI, Basel, Switzerland. This article is an open access article distributed under the terms and conditions of the Creative Commons Attribution (CC BY) license (https:// creativecommons.org/licenses/by/ $4.0 /)$.

\begin{abstract}
Understanding the evolution of farmers' livelihood strategies (FLS) is crucial for maintaining the sustainable development of farmers' livelihoods, especially on the arid Loess Plateau, China. This study constructed a novel analytical framework for analyzing the evolution of FLS and the critical influencing factors. Changwu County, an apple cultivation region, was selected as a case study. The results suggest that four types of livelihood strategies (crop-planting, apple-planting, work-oriented, and part-time comprehensive) have emerged since the 1980s. The evolutionary process of leading FLS varies across geographic location. In the loess tableland region and economic fringe region, this evolution followed a progressive path from the crop-planting type to the apple-planting type to the work-oriented type, while in the loess gully region, loess ridge region, and economic core region, FLS jumped directly from the crop-planting type to the work-oriented type. The geographic location, training opportunities, garden area, cultivated land area, production and living materials, loan opportunities, and education level were found to be the critical factors influencing the differentiation and development of FLS. The analytical framework proposed here is also applicable for studying the evolution of FLS in other counties on the Loess Plateau, considering the representativeness of the selected case.
\end{abstract}

Keywords: livelihood strategy; farmers; evolution and development; geographic location; livelihood capital

\section{Introduction}

A livelihood comprises the capabilities, capital (including both material and social resources), and activities required for a means of living [1-3]. The livelihoods of farmers in developing countries and regions have attracted much attention, especially in remote and ecologically fragile regions [4-8]. Due to low urbanization and slow livelihood diversification, most farmers in these regions have relied on natural resources to maintain their livelihoods. However, farmers' livelihood activities have been changing continuously with developments in social productivity. Existing studies have found that, affected by various disturbances, farmers either actively or passively give up their original livelihood activities and seek new ones, creating new livelihood strategies [9-11]. Affected by the development of rural society and the economy, the trend toward part-time and non-agricultural activities in farmers' livelihood strategies (FLS) in developing countries seems inevitable. The applicability of livelihood strategies not only affects the efficiency of the use of livelihood capital, but is also the key to livelihood outcome and stability, which play important roles in the continuous and stable operation of the entire livelihood system [12-14]. Therefore, it is of great practical value to understand FLS and their evolution.

A livelihood strategy refers to the way that farmers combine and use different forms of livelihood capital to achieve livelihood goals or pursue active livelihood outcomes [1,2,15]. For the past 30 years, studies on FLS have mainly focused on the diversification livelihood 
strategy and poverty, and livelihood strategies and their influencing factors. Scoones divided FLS into four types: the extensification livelihood strategy, the agricultural intensification livelihood strategy, the diversification livelihood strategy, and the migration livelihood strategy [3]. Among them, the diversification livelihood strategy is a process in which farmers rely on a combination of diversification livelihood activities and social support capabilities to meet their needs in terms of maintaining and improving their livelihoods [13]. Many scholars have explored the effect of the diversification livelihood strategy on the livelihood system of farmers, and concluded that this strategy is not only conducive to improving the livelihood adaptability of farmers to external disturbances, but also has a positive impact on eliminating poverty and improving livelihood outcomes [16-20]. For example, Ho et al., revealed that the diversification livelihood strategy can reduce risks and the uncertainties of livelihoods [21]. Through studies on the diversification of the non-agricultural livelihood strategy in Zambia, Nambeye et al., indicated that insufficient agricultural outcome is an important reason for farmers to adjust their livelihood strategy to the diversified livelihood strategy, which will bring diversified sources of income [22]. Tukela et al., explored the relationship between strategy and poverty in the Sidama Region, Ethiopia, and indicated that the diversification livelihood strategy is more likely to reduce household poverty [23]. The above studies show that the diversification livelihood strategy is of great significance for maintaining livelihood stability and reducing poverty.

With the continuous deepening of related research, studies have gradually begun to focus on the influencing factors of FLS. However, most existing studies explored the effect on FLS from a single factor perspective. Some scholars have investigated the similarities and differences in FLS in different locations in a diversified region to demonstrate the role of geographic location in the formation and development of FLS [24,25]. Complicated terrain conditions and differences in economic development among regions have caused heterogeneity in the regional development conditions of farmers' livelihoods, resulting in the differentiation of FLS. Moreover, considering the development of social productivity, some scholars have paid attention to the impact of climate change, land use, policies, and other factors on FLS [26-33]. Raihan et al., explored the impact of farmers' adaptive choice of livelihood strategies in the face of climate change [34]. Mulatie et al., studied the impact of internal migration on the FLS in southwest Ethiopia [35]. Tang et al., studied the impact of returning farmland to forests on the FLS on the Loess Plateau [36]; Sun et al., explored the influencing path of Targeted Poverty Alleviation policies on FLS in China [37]. The research results of Mondal et al., show that the tourism-oriented transfer of FLS contributes to the outcome of FLS [38]. In addition, livelihood capital is a prerequisite for farmers' livelihood activities and plays a supporting role in the formation of FLS [39-43]. Farmers seek the best livelihood strategies by combining different types of capital to maintain their livelihood security $[44,45]$. On this basis, scholars have conducted a large number of empirical studies on the impact of farmers' livelihood capital on FLS in developing countries and regions, which is of great relevance to the sustainable development of farmers' livelihoods [46-50]. For example, He et al., studied the impact of human capital on FLS in Liangshan, Sichuan, and concluded that human capital such as education, culture, and health status has a positive impact on the choice of non-agricultural livelihood strategies [51]. By studying the role of non-timber products in the FLS in the drylands of Sudan, Adam et al., revealed that natural capital is of great significance to the development of FLS in developing countries [52]. Nath's empirical research in coastal Bangladesh shows that different combinations of livelihood capital lead to different combinations of livelihood strategies [53]. Malherbe et al., studied the impact of social capital on FLS in the Solomon Islands, and concluded that the accumulation of livelihood capital contributes to the development of diversified livelihood strategies of farmers [54]. In contrast, few studies have explored the differentiation and development of FLS from a comprehensive perspective that considers multiple factors.

In reviewing the literature, we found that the existing studies are, in some ways, insufficient. First, FLS are constantly adjusted in response to the development of productivity. 
The existing body of research is composed primarily of static studies on the status of FLS in a single period, while dynamic studies on the evolution of FLS are relatively scarce. Second, it is necessary to construct an analytical framework that considers the influence of multiple variables to explore the dynamic evolution of FLS.

China is the largest developing country in the world. According to the China Rural Statistical Yearbook 2020 (https: / / data.cnki.net/yearbook/Single/N2020120306 (accessed on 5 October 2021), at the end of 2019, the rural population was 551.62 million, accounting for $39.4 \%$ of the total population. The sustainable livelihoods of the rural population have become an important part of China's "Rural Revitalization Strategy". Since the reform and opening up, China's rural household structure and population employment characteristics have undergone tremendous changes. Members of the young generation at the beginning of the reform and opening up are now mostly 50-60 years old, and they have experienced the process of agricultural production that involves going out to work and then returning home to engage in agricultural production. In addition, the subsequent generation and new generation of families have been gradually separated from the traditional extended family. Due to the lack of agricultural production skills, family livelihood activities have gradually shifted to non-agricultural work. Elderly people are engaged in agricultural production, while among younger workers, leaving home to work has become the primary means of expanding rural livelihoods in China. The Loess Plateau is a representative area of traditional agricultural production and the main production area of grain crops in China. Since the reform and opening up, global climate change, agricultural technology development, ecological protection policies, urbanization, and industrialization have considerably altered the development environment of traditional rural areas on the Loess Plateau. The employment direction has shifted from agricultural to non-agricultural work, the economic structure has shifted from primary industry to secondary and tertiary industries, and the agricultural crop structure has shifted from grain crop planting to cash crops represented by fruits [55-58]. With these changes in the regional rural development environment, FLS have also continued to differentiate and develop. Understanding the dynamic evolution characteristics of FLS can provide insights for policies targeting the healthy development of household livelihoods and the rural economy on the Loess Plateau in the context of rural transformation. In addition, this information has important strategic value for the overall realization of rural revitalization in China.

Based on the regional development characteristics of the Loess Plateau, and drawing on existing studies of farmers' livelihoods, this paper constructed an analytical framework specifically applicable to studying the evolution of FLS on the Loess Plateau. We selected Changwu County, an apple cultivation region on the Loess Plateau, as the case study area. The formation and evolution of FLS were investigated based on survey data from farmers. This study aims to answer the following questions:

(1) How have FLS evolved?

(2) What are the main factors that have influenced the evolution of FLS?

The remainder of this paper is organized as follows. In Section 2, we construct the analytical framework for FLS evolution. Section 3 presents the study area, study data, and research methodology. Section 4 presents the research results of the evolution process of FLS, influencing factors of FLS, and influence mechanisms. Section 5 discusses the role of geographic location and livelihood capital in the evolution of FLS, the similarities and differences with existing research, policy implications, the limitations of the study, and future research. Finally, main conclusions of the study are presented in Section 6.

\section{Analytical Framework}

Multiple existing sustainable livelihood analytical frameworks, namely, the Sustainable Livelihoods Approach (SLA) established by the UK's Department for International Development (DFID) [2], the Livelihood Security Framework of Farmers proposed by the Cooperative for American Remittances to Everywhere (CARE) [59], and the Sustainable Livelihood Approach proposed by the United Nations Development Programme 
(UNDP) [60], have been developed. However, these frameworks focus on different aspects of sustainable livelihoods. The SLA framework established by the DFID is the most widely adopted and applied, and has become the classic paradigm for farmer livelihood analysis. The SLA framework regards farmers as subjects who have certain forms of livelihood capital that they use to earn a living in a context of vulnerability. The acquisition of this livelihood capital is determined by the social, institutional, and organizational environment. This environment also affects the strategies that farmers use to meet their livelihood goals. However, because the framework encompasses the entire livelihood system, it provides insufficient information on specific intermediate links. In addition, the framework is designed not for seeking a universal solution, but for supporting analytical thinking. Therefore, it is necessary to adjust the framework according to the study area in specific applications. For example, Chen et al., analyzed the livelihood adaptability of farmers in the Minqin Oasis through an improved adaptive livelihood framework [39], and Tang et al., used an improved livelihood framework to analyze the livelihood sustainability of farmers on the Loess Plateau affected by the "Grain for Green" program [36]. By referencing the SLA and accounting for the regional geographical environment, we constructed an analytical framework for studying the evolution of FLS on the Loess Plateau (Figure 1). In this framework, the livelihood strategy is the core, and its formation and evolution are influenced by geographic location-related factors (economic location, terrain location) and various forms of livelihood capital under a uniform policy environment. According to this framework, we conducted study on the evolution of FLS on the Loess Plateau.

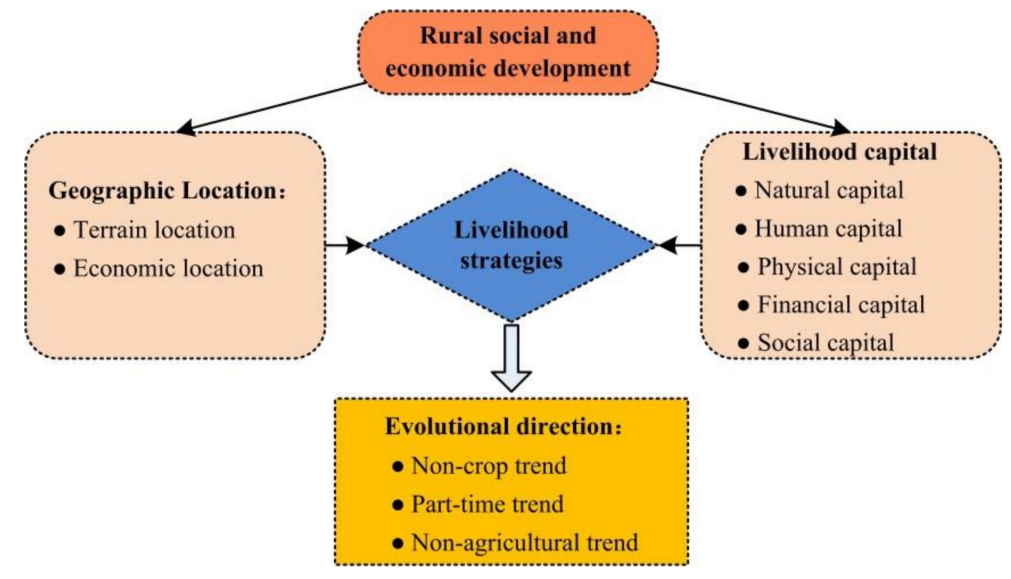

Figure 1. Analytical framework for FLS evolution.

\section{Materials and Methods}

\subsection{Study Area}

Changwu County is an apple cultivation region located on the southern Loess Plateau in northwestern China (ranging from $107^{\circ} 38^{\prime}$ to $107^{\circ} 59^{\prime} \mathrm{E}$ and from $34^{\circ} 59^{\prime}$ to $35^{\circ} 18^{\prime} \mathrm{N}$ ) (Figure 2A, the location of the Loess Plateau in China; Figure 2B, the location of Changwu County on the Loess Plateau; Figure 2C, the location overview of Changwu County). The total area of the county is $568.26 \mathrm{~km}^{2}$, and there are seven towns and one community under the jurisdiction of the county (Figure 2C). Among them, Zhaoren Subdistrict, Tingkou Town, and Dingiia Town are gradually becoming the urbanized and economic core areas of Changwu County because they are an administrative center, coal production region, and industrial park, while the remaining towns located in agricultural production regions have become the economic fringe regions of this county. The terrain of the county is primarily loess tableland, loess gully, and loess ridge. The elevation is higher in the southwestern part and lower in the northeastern part, forming a typical loess plateau gully landform in the northern reaches of the Weihe River, the largest anabranch of the Yellow River. 

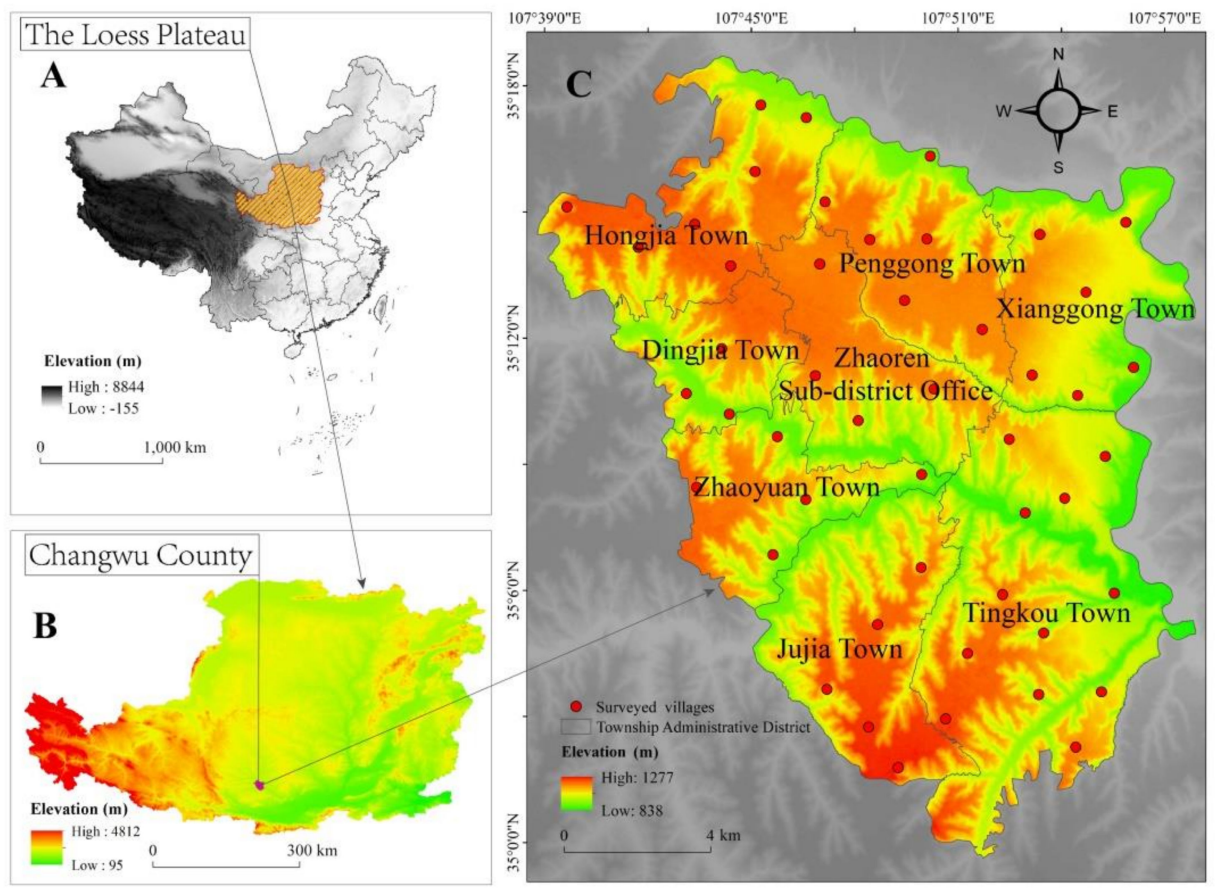

Figure 2. Location of the study site on the Loess Plateau, China.

Changwu County has a long history of farming dating back over 1000 years, and it is a typical region for traditional dryland agriculture in China. Since the early 1990s, the proportion of the agricultural sector occupied by apple cultivation has gradually increased (Figure 3). As the proportion of apple-planted land continues to grow, income from apple orchards has become a major component of local income. This change led to a transition in the rural economic system from a traditional crop-planted regime to a regime of non-crop agriculture from 2006 to 2015. In addition, the county is rich in coal resources. The development of coal-related industries has greatly promoted the processes of industrialization and urbanization, resulting in an increasing transfer of agricultural labor to non-agricultural industries since the early 2000s (Figure 4). Non-agricultural income has become the main source of income in the rural economy, leading to a transition in the rural economic system from an agricultural production regime to a nonagricultural regime, beginning in 2015 and continuing to the present. With the continuous transformation of the rural economic system, FLS have continued to develop and diverge.

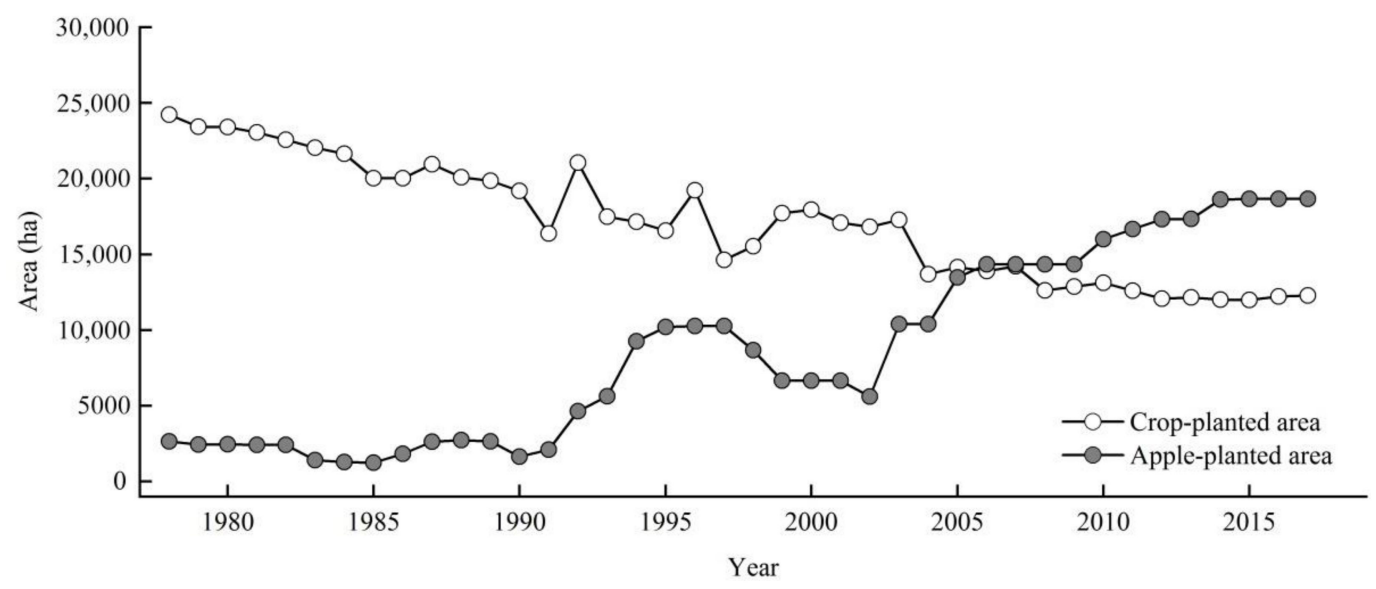

Figure 3. Changes in the rural crop structure in Changwu County. 


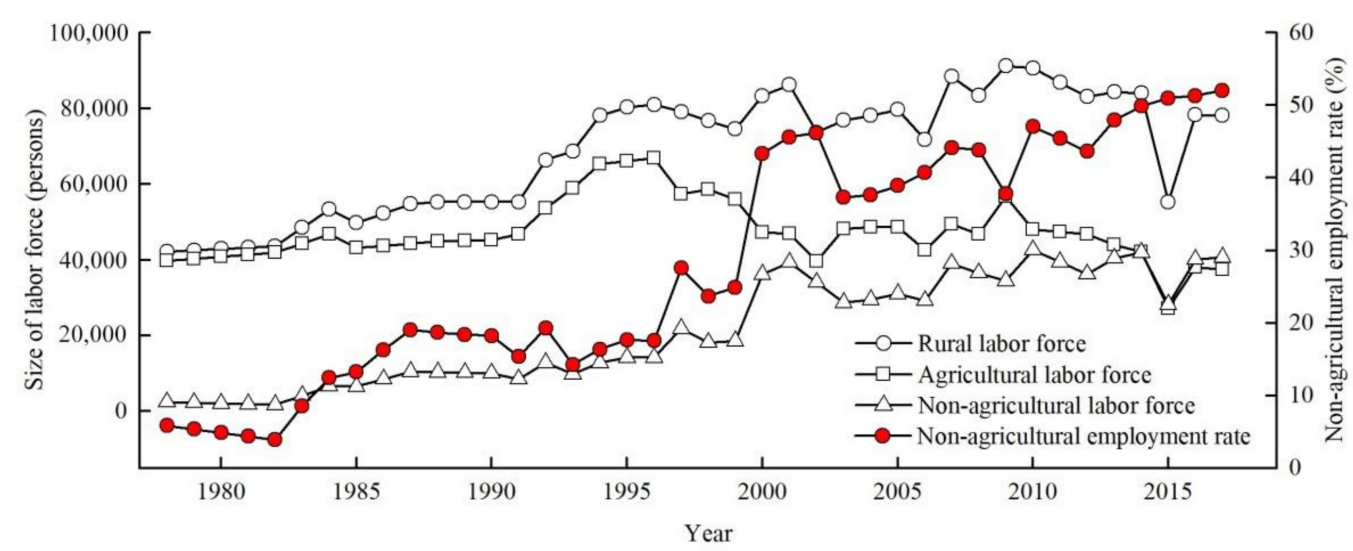

Figure 4. Changes in the rural employment structure in Changwu County.

\subsection{Sampling and Data Collection}

The data used in this study include statistical and survey data. The social and economic statistics come from the Changwu County Statistical Yearbooks from 1978 to 2018. The acquisition of the survey data was carried out in three stages. First, the research team went to Changwu County to conduct a pre-survey from 25 March to 29 March 2019. Through visits to officials from the government departments of Changwu County, such as the Bureau of Statistics, the Bureau of Agriculture, the Bureau of Natural Resources, and the Bureau of Fruit Industry, we learned more about the changes in crop structure, labor force employment, apple planting, and key events in rural development since 1980. Moreover, six villages were randomly selected, two farmers in each village were selected for the pre-survey, and the content of the questionnaire was revised and improved. Next, we conducted a formal survey from 4 August to 20 August 2019. According to the terrain characteristics, social and economic development levels, and population distribution characteristics, 48 administrative villages were selected as survey points, accounting for $36.09 \%$ of the total number of administrative villages in Changwu County (there were 133 administrative villages in Changwu County in 2019). A total of 243 questionnaires were collected by random sampling, accounting for $1.81 \%$ of the total number of farmers in all surveyed villages (there were 13,422 farmers in the surveyed villages in 2019, and there were 41,967 farmers in Changwu County). Finally, 233 surveys were found to be valid, with 134 from farmers in the loess tableland region, 39 from farmers in the loess ridge region, and 60 from farmers in the loess gully region. A total of 99 surveys were collected from farmers in the economic core region, and 134 were collected from farmers in the economic fringe region. The questionnaire mainly assessed the livelihood capital, livelihood activities, and income structure of farmers in different periods (1990, 2000, 2010 and 2018). Finally, we conducted a supplementary survey from 11 October to 15 October 2019. We randomly selected the heads of 20 surveyed villages from different regions for a 30-50 min semi-structured interview. Among these heads of the surveyed villages, eight were from the loess tableland region, six were from the loess ridge region, six were from the loess gully region, fifteen were from the economic fringe region, and five were from the economic core region. The interview content included (1) the history of and reason for apple planting in the villages; (2) the main factors restricting the development of the village and the future development direction; and (3) the evolution process of population outflow and labor migration. The interview data can provide reference and support for the interpretation of the research results.

\subsection{Classification Criteria for FLS}

According to the survey, the livelihood activities of the farmers in the study region are mainly crop cultivation, apple cultivation, and non-agricultural work. According to the proportion of income obtained via various livelihood activities, the FLS were divided into four 
types: the crop-planting livelihood strategy (CPLS), the apple-planting livelihood strategy (APLS), the work-oriented livelihood strategy (WOLS), and the part-time comprehensive livelihood strategy (PTLS). The classification criteria are shown in Table 1.

Table 1. The classification criteria for FLS.

\begin{tabular}{|c|c|c|}
\hline Livelihood Strategies & Livelihood Activity Portfolio & Income Structure \\
\hline $\begin{array}{l}\text { Crop-planting livelihood } \\
\text { strategy (CPLS) }\end{array}$ & $\begin{array}{l}\text { Crop cultivation and } \\
\text { other activities }\end{array}$ & $\begin{array}{l}\text { Income from crop cultivation } \\
\text { accounts for more than } 50 \% \text { of the } \\
\text { total annual household income. }\end{array}$ \\
\hline $\begin{array}{l}\text { Apple-planting livelihood } \\
\text { strategy (APLS) }\end{array}$ & $\begin{array}{l}\text { Apple cultivation and } \\
\text { other activities }\end{array}$ & $\begin{array}{l}\text { Income from apple cultivation } \\
\text { accounts for more than } 50 \% \text { of the } \\
\text { total annual household income. }\end{array}$ \\
\hline $\begin{array}{l}\text { Work-oriented livelihood } \\
\text { strategy (WOLS) }\end{array}$ & $\begin{array}{l}\text { Non-agricultural work and } \\
\text { other activities }\end{array}$ & $\begin{array}{c}\text { Income from non-agricultural } \\
\text { work accounts for more than } 50 \% \\
\text { of the total annual } \\
\text { household income. }\end{array}$ \\
\hline $\begin{array}{l}\text { Part-time comprehensive } \\
\text { livelihood strategy (PTLS) }\end{array}$ & $\begin{array}{l}\text { Crop and apple cultivation, } \\
\text { non-agricultural work, and } \\
\text { other activities }\end{array}$ & $\begin{array}{l}\text { Family engaged in at least two } \\
\text { livelihood activities, and the } \\
\text { proportion of the family's total } \\
\text { annual income from each } \\
\text { livelihood activity is not more } \\
\text { than } 50 \% \text {. }\end{array}$ \\
\hline
\end{tabular}

\subsection{Binary Logistic Regression Method}

When the dependent variable is derived from qualitative data, binary logistic regression is a widely accepted approach. This method determines the function and intensity of variable $x_{i}$ in predicting the occurrence probability of dependent variable $y$. The FLS were taken as dependent variables (value set to 0 or 1 ). The index of farmers' livelihood capital and geographic location were the independent variables. Binary logistic regression analysis was used to analyze the key factors influencing FLS. The conditional probability of $y$ is:

$$
y=\operatorname{In}\left[\frac{p}{1-p}\right]=\beta_{0}+\beta_{1} x_{1}+\beta_{2} x_{2}+\cdots \beta_{i} x_{i}
$$

The corresponding logistic regression model is:

$$
P=\frac{\exp \left(\beta_{0}+\beta_{1} x_{1}+\beta_{2} x_{2}+\cdots+\beta_{i} x_{i}\right)}{1+\exp \left(\beta_{0}+\beta_{1} x_{1}+\beta_{2} x_{2}+\cdots+\beta_{i} x_{i}\right)}
$$

where $P$ is the probability of selecting one type of livelihood strategy and $x_{1}, x_{2}, \ldots x_{i}$ are independent variables. Parameters $\beta_{0}, \beta_{1}, \beta_{2}, \ldots \beta_{i}$ are the undetermined regression coefficients.

The independent variables selected for the binary logistic regression were two geographic location dimensions and livelihood capital. The geographic location variables were the terrain location and economic location of the farmers (Table 2). In terms of livelihood capital, based on the sustainable livelihood framework [2] and considering the actual situation of the research region, we selected relevant variables from natural capital, human capital, physical capital, financial capital, and social capital (Table 2). A statistical description of each variable is presented in Table A1 in Appendix A. 
Table 2. Independent variables used in the binary logistic regression.

\begin{tabular}{|c|c|c|}
\hline Dimension & Variable & Description \\
\hline \multirow[t]{2}{*}{$\begin{array}{l}\text { Geographic } \\
\text { location }\end{array}$} & Economic location & $\begin{array}{l}\text { According to the industrial layout and economic development of } \\
\text { Changwu County, the economic areas can be divided into the } \\
\text { economic fringe region and economic core region: economic } \\
\text { fringe region }=1 \text {, economic core region }=2 \text {. }\end{array}$ \\
\hline & Terrain location & $\begin{array}{l}\text { The terrain of Changwu County is mainly divided into three } \\
\text { types: loess ridge, loess tableland, and loess gully, and the values } \\
\text { were assigned according to the quality of the regional agricultural } \\
\text { production conditions: loess gully region }=1 \text {, loess ridge } \\
\text { region }=2 \text {, loess tableland region }=3 \text {. }\end{array}$ \\
\hline \multirow[t]{2}{*}{ Natural capital } & Cultivated land area & $\begin{array}{l}\text { Per capita cultivated area: the ratio of actual cultivated area to the } \\
\text { total number of household members. }\end{array}$ \\
\hline & Garden area & $\begin{array}{l}\text { Per capita garden area: the ratio of actual garden area to the total } \\
\text { number of household members. }\end{array}$ \\
\hline \multirow[t]{2}{*}{ Human capital } & Labor force & $\begin{array}{l}\text { The proportion of laborers per household: the ratio of laborers } \\
\text { (16-65 years old) to total household members. }\end{array}$ \\
\hline & Education level & $\begin{array}{l}\text { Per capita years of education: the ratio of total years of family } \\
\text { education to the total number of household members. }\end{array}$ \\
\hline Physical capital & Production and living materials & $\begin{array}{l}\text { The number of main production and living tools owned by a } \\
\text { household selected by the farmer from the questionnaire. }\end{array}$ \\
\hline \multirow[t]{2}{*}{ Financial capital } & Credit opportunities & $\begin{array}{l}\text { Binary variable representing bank lending opportunities } \\
\text { according to whether a bank loan can be obtained: yes }=1, \text { no }=0 \text {. }\end{array}$ \\
\hline & Loan opportunities & The number of people who can lend the family money. \\
\hline \multirow[t]{3}{*}{ Social capital } & Social network & $\begin{array}{l}\text { Binary variable representing whether someone in the family } \\
\text { works in a government department: yes }=1, \text { no }=0 .\end{array}$ \\
\hline & Neighborhood trust & Trust in neighbors on a five-point scale. \\
\hline & Training opportunities & The level of production skills training that farmers can receive. \\
\hline
\end{tabular}

\section{Results}

\subsection{Characteristics of Different FLS}

Since the 1980s, farmers in Changwu County have adopted four main livelihood strategies (i.e., CPLS, APLS, WOLS, and PTLS), all of which play an important role in the development of farmers' livelihoods in the process of rural development.

CPLS: This livelihood strategy was formed after the establishment of the Household Contract Responsibility System and focuses primarily on crop cultivation. As farmers were limited by the level of productivity development, land immediately became the major means of production for them. Therefore, the CPLS became the leading livelihood strategy in the study region. Since then, farmers have gradually resolved the problem of obtaining food and clothing. However, with the rapid development of productivity levels, the status of the CPLS gradually declined in the early 21st century.

APLS: This type of livelihood strategy, with apple cultivation as the main livelihood activity, emerged in the late 1980s. At that time, the Institute of Soil and Water Conservation at the Chinese Academy of Sciences used apple cultivation to prevent soil erosion, and experimented in several villages in Hongjia Town. Driven by economic benefits and policy support, apple cultivation gradually expanded from the pilot region to the whole county. Around the turn of the 21st century, the APLS became the leading livelihood strategy and helped improve the income level of rural farmers. At present, the APLS is still mainly followed in loess tableland region villages with superior apple growing conditions.

WOLS: This livelihood strategy, with non-agricultural work as the main livelihood activity, emerged in the late 1990s. It was initially pursued in the economic core region and loess gully region. With the development of productivity, surplus rural labor began to 
appear, and coupled with the decline in apple earnings, non-agricultural work became the main livelihood activity of farmers. The WOLS also became the leading livelihood strategy in rural areas. This livelihood strategy not only improved the economic income of farmers, but also pushed the rural economic system into the non-agricultural phase.

PTLS: This livelihood strategy was formed in the late 1990s and is characterized by diverse livelihood activities and a relative balance among different income sources. Livelihood activities mainly take the form of a combination of crop cultivation, apple cultivation, and non-agricultural work. The PTLS not only reduced livelihood risks, but also increased and stabilized farmers' household income.

\subsection{Evolution of FLS}

Since the 1980s, FLS have evolved in accordance with the regime shifts in the rural economic system in Changwu County. However, the evolution of FLS has followed different patterns under different geographic locations.

\subsubsection{Evolution of FLS in Different Economic Sub-Regions}

In 1990, FLS in the economic fringe region were mainly based on the CPLS, which was adopted by $76.87 \%$ of the surveyed farmers (Figure 5a, the FLS composition of households surveyed in the economic fringe region). By 2000, the APLS had been adopted by $47.76 \%$ of the surveyed farmers, making it the leading livelihood strategy (Figure 5a). Driven by the difference in economic benefits among industries, the WOLS was followed by $47.76 \%$ of the surveyed farmers in 2010, making it the leading livelihood strategy in the economic fringe region (Figure 5a). Compared with the economic fringe region, the proportion of farmers using the CPLS decreased from $90.91 \%$ in 1990 to $18.18 \%$ in 2000 , and the proportion using the WOLS increased from $0.00 \%$ in 1990 to $53.54 \%$ in 2000 , making it the dominant livelihood strategy in the economic core region (Figure 5b, the FLS composition of households surveyed in the economic core region).
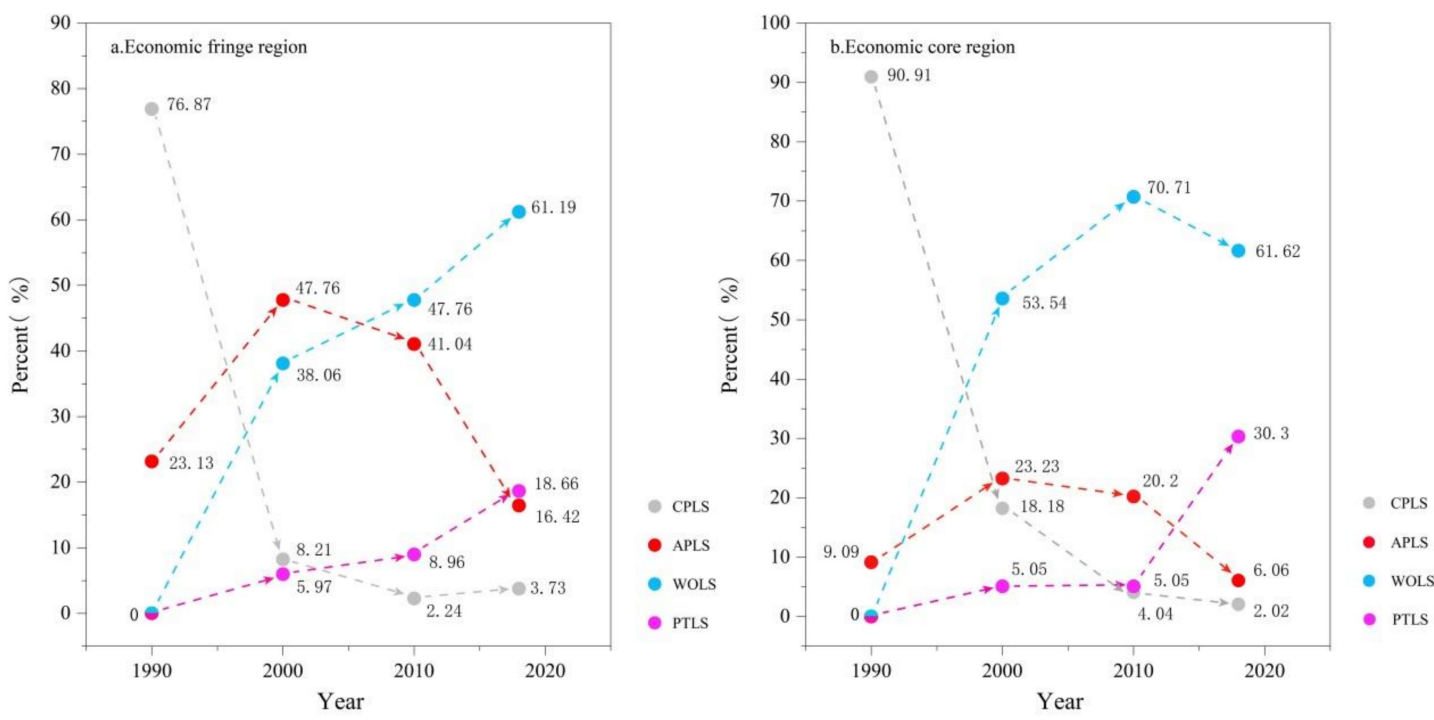

Figure 5. The FLS composition of households surveyed in different economic sub-regions in different periods.

\subsubsection{Evolution of FLS in Different Terrain Sub-Regions}

The development of the fruit industry led the proportion of farmers using the CPLS to decrease from $79.85 \%$ in 1990 to $9.70 \%$ in 2000 , while the proportion using the APLS increased from $20.15 \%$ in 1990 to $44.03 \%$ in 2000 in the loess tableland region. Apple cultivation thus became the major livelihood activity in the loess tableland region (Figure 6c, the FLS composition of households surveyed in the loess tableland region). With the 
advancement of industrialization and the decline in the economic benefits of apple growing, the proportion of farmers adopting the WOLS increased from $41.79 \%$ in 2000 to $50.75 \%$ in 2010, making it the leading livelihood strategy for regional farmers. In contrast, the proportions of farmers using the CPLS in the loess gully region and the loess ridge region were $88.33 \%$ and $84.62 \%$ in 1990, respectively (Figure 6a, the FLS composition of households surveyed in the loess gully region; Figure $6 \mathrm{~b}$, the FLS composition of households surveyed in the loess ridge region). By 2000, the proportions of farmers using the CPLS dropped to $13.33 \%$ and $20.51 \%$ in the loess gully region and loess ridge region, respectively, while the proportions using the WOLS increased to $58.33 \%$ and $33.33 \%$ in 2000 . This made the WOLS the leading livelihood strategy, a situation that remained unchanged until 2018 (Figure 6a,b).
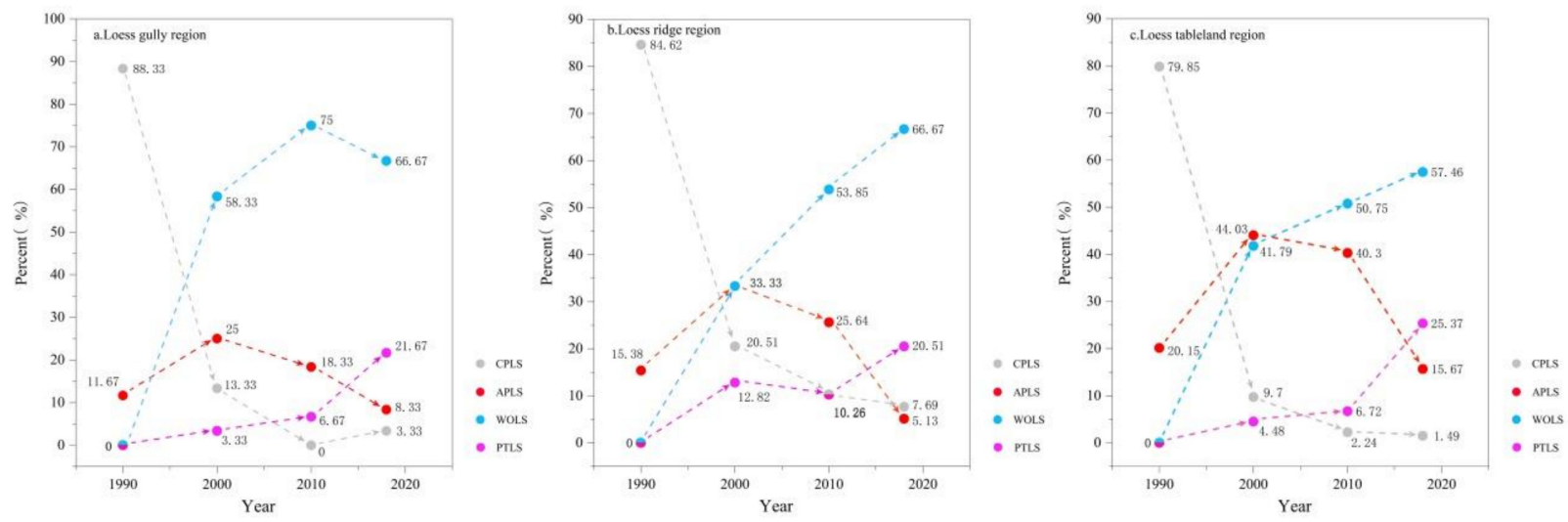

Figure 6. The FLS composition of households surveyed in different terrain sub-regions in different periods.

\subsubsection{The Evolution Path of FLS}

From the above analysis, it can be seen that the FLS in the study area have evolved to the direction of non-crop and non-agricultural. However, the evolution of FLS varies across geographic locations. The evolution of FLS followed a progressive path from the CPLS to the APLS to the WOLS in the loess tableland region and economic fringe region (Figure 7), and the non-agricultural process of FLS development was slower; however, it followed a jump path that jumped directly from the CPLS to the WOLS in the loess gully region, loess ridge region, and economic core region (Figure 7), and the non-agricultural process of FLS development was faster.

\subsection{Factors Influencing FLS Evolution}

Within the analytical framework, we used binary logistic regression to explore the influence of geographic location and livelihood capital on the evolution of FLS. The dependent variable: FLS in various periods, and the independent variables: livelihood capital and the geographic location of farmers, were calculated using the system default entry method. Among the 14 livelihood strategy regression models, 13 had a significance level greater than 0.05 according to the Hosmer-Lemeshow test, with only the PTLS in 2010 failing to pass the test. The fit results of all of these models were acceptable, with a prediction accuracy of approximately 20\% to 30\% (Table A2 in Appendix A). All 13 models had strong explanatory power. It is noted that in the CPLS model for 2010, none of the variables passed the significance test (Table 3). 


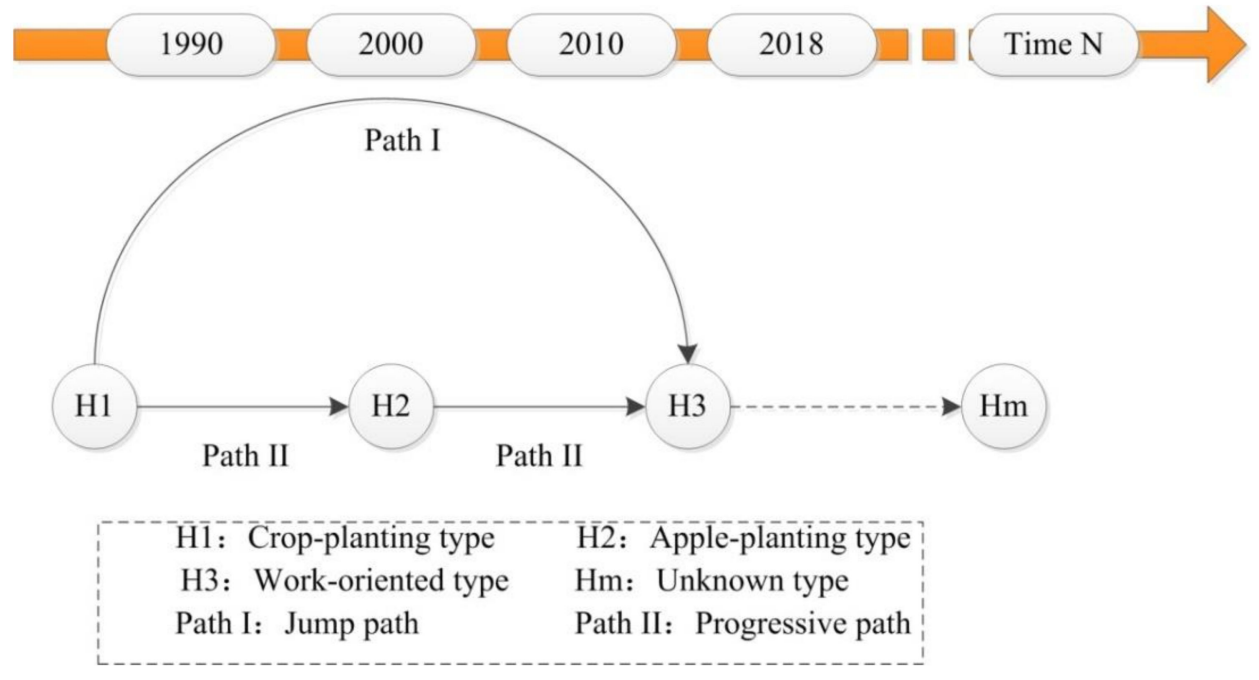

Figure 7. The evolution path of leading livelihood strategy.

Table 3. Logistic regression analysis results of the factors influencing FLS.

\begin{tabular}{|c|c|c|c|c|c|c|c|}
\hline $\begin{array}{c}\text { Livelihood } \\
\text { Strategies }\end{array}$ & Period & $\begin{array}{l}\text { Independent } \\
\text { Variable }\end{array}$ & $\begin{array}{l}\text { Regression } \\
\text { Coefficient } \\
\text { (B) }\end{array}$ & $\begin{array}{l}\text { Standard } \\
\text { Error } \\
\text { (SE) }\end{array}$ & Wald & $\begin{array}{l}\text { Significance } \\
\text { (Sig) }\end{array}$ & $\begin{array}{l}\text { Odds Ratio } \\
\text { Exp (B) }\end{array}$ \\
\hline \multirow{6}{*}{ CPLS } & 1990 & Training opportunity & -0.872 & 0.218 & 16.038 & 0.000 & 0.418 \\
\hline & 2000 & Garden area & -1.629 & 0.676 & 5.815 & 0.016 & 0.196 \\
\hline & \multirow{4}{*}{2018} & $\begin{array}{l}\text { Production and } \\
\text { living materials }\end{array}$ & -0.709 & 0.257 & 7.588 & 0.006 & 0.492 \\
\hline & & Loan opportunities & -0.273 & 0.127 & 4.639 & 0.031 & 0.761 \\
\hline & & Cultivated land area & 0.796 & 0.392 & 4.116 & 0.042 & 2.216 \\
\hline & & Economic location & -2.328 & 1.138 & 4.185 & 0.041 & 0.097 \\
\hline \multirow{9}{*}{ APLS } & 1990 & $\begin{array}{c}\text { Training } \\
\text { opportunities }\end{array}$ & 0.872 & 0.218 & 16.038 & 0.000 & 2.392 \\
\hline & 2000 & Garden area & 1.752 & 0.473 & 13.726 & 0.000 & 5.764 \\
\hline & \multirow{3}{*}{2010} & $\begin{array}{c}\text { Training } \\
\text { opportunities }\end{array}$ & 0.578 & 0.181 & 10.188 & 0.001 & 1.783 \\
\hline & & Garden area & 2.268 & 0.514 & 19.454 & 0.000 & 9.659 \\
\hline & & $\begin{array}{c}\text { Training } \\
\text { opportunities }\end{array}$ & 0.404 & 0.150 & 7.286 & 0.007 & 1.498 \\
\hline & \multirow[t]{4}{*}{2018} & Garden area & 1.972 & 0.581 & 11.521 & 0.001 & 7.187 \\
\hline & & Education level & -0.882 & 0.368 & 5.740 & 0.017 & 0.414 \\
\hline & & Loan opportunities & 0.228 & 0.109 & 4.351 & 0.037 & 1.256 \\
\hline & & Terrain location & 0.564 & 0.385 & 2.140 & 0.014 & 1.758 \\
\hline \multirow{7}{*}{ WOLS } & 2000 & $\begin{array}{c}\text { Training } \\
\text { opportunities }\end{array}$ & -0.575 & 0.192 & 8.936 & 0.003 & 0.563 \\
\hline & 2010 & Garden area & -1.407 & 0.436 & 10.418 & 0.001 & 0.245 \\
\hline & \multirow{5}{*}{2018} & $\begin{array}{c}\text { Training } \\
\text { opportunities }\end{array}$ & -0.407 & 0.148 & 7.509 & 0.006 & 0.666 \\
\hline & & Economic location & 0.536 & 0.324 & 2.738 & 0.009 & 1.709 \\
\hline & & Cultivated land area & -0.570 & 0.162 & 12.368 & 0.000 & 0.565 \\
\hline & & Garden area & -0.974 & 0.404 & 5.796 & 0.016 & 0.378 \\
\hline & & Terrain location & -0.453 & 0.210 & 4.677 & 0.031 & 0.636 \\
\hline \multirow[t]{2}{*}{ PTLS } & 2000 & $\begin{array}{c}\text { Training } \\
\text { opportunities }\end{array}$ & -0.872 & 0.218 & 16.038 & 0.000 & 0.418 \\
\hline & 2018 & Cultivated land area & 0.319 & 0.134 & 5.705 & 0.017 & 1.376 \\
\hline
\end{tabular}

The regression results suggested that the geographic location, training opportunities, garden area, cultivated land area, production and living materials, and loan opportunities 
and education level, as part of livelihood capital, were the major factors influencing the differentiation and development of FLS (Table 3). In terms of geographic location, under certain productivity levels, economic location had a significantly negative impact on the CPLS and a significantly positive impact on the WOLS, and terrain location had a significantly negative impact on the WOLS and a significantly positive impact on the APLS. In terms of livelihood capital, training opportunities in social capital had a significantly negative impact on the CPLS, WOLS, and PTLS, and a significantly positive impact on the APLS at different times. Garden area in natural capital had a significantly negative impact on the CPLS, WOLS, and PTLS, and a significantly positive impact on the APLS at different times. Cultivated land area in natural capital had a significantly negative impact on the WOLS, and a significantly positive impact on the CPLS and PTLS at different times. Loan opportunities in financial capital had a significantly positive impact on the APLS and a significantly negative impact on the CPLS at different times. In addition, education level in human capital had a significantly negative impact on the APLS in 2018, and production and living materials in physical capital had a significantly negative impact on the CPLS in 2000.

\subsection{Mechanism of the Factors Influencing FLS Evolution}

The evolution of rural FLS was affected by the combination of geographic location and livelihood capital during the rural social and economic development of Changwu County (Figure 8). Geographic location determined the environment of farmers' livelihood development. Different geographic location caused differences in farmers' resource endowments, industrial development conditions, job opportunities, and degrees of contact with other regions, which, in turn, affected the choice and direction of the development of FLS. In addition, the stock of livelihood capital and its support of the livelihood system changed with the development of rural production. Driven by survival and economic rationales, farmers adjusted the use of their livelihood capital in a timely manner and changed their livelihood strategies to adapt to the development of productivity and increase their income. In summary, the differentiation and development of FLS in Changwu County was the result of farmers' rational allocation of livelihood capital among different livelihood activities under the restrictive or promotional influences of their location conditions in the process of rural social and economic development.

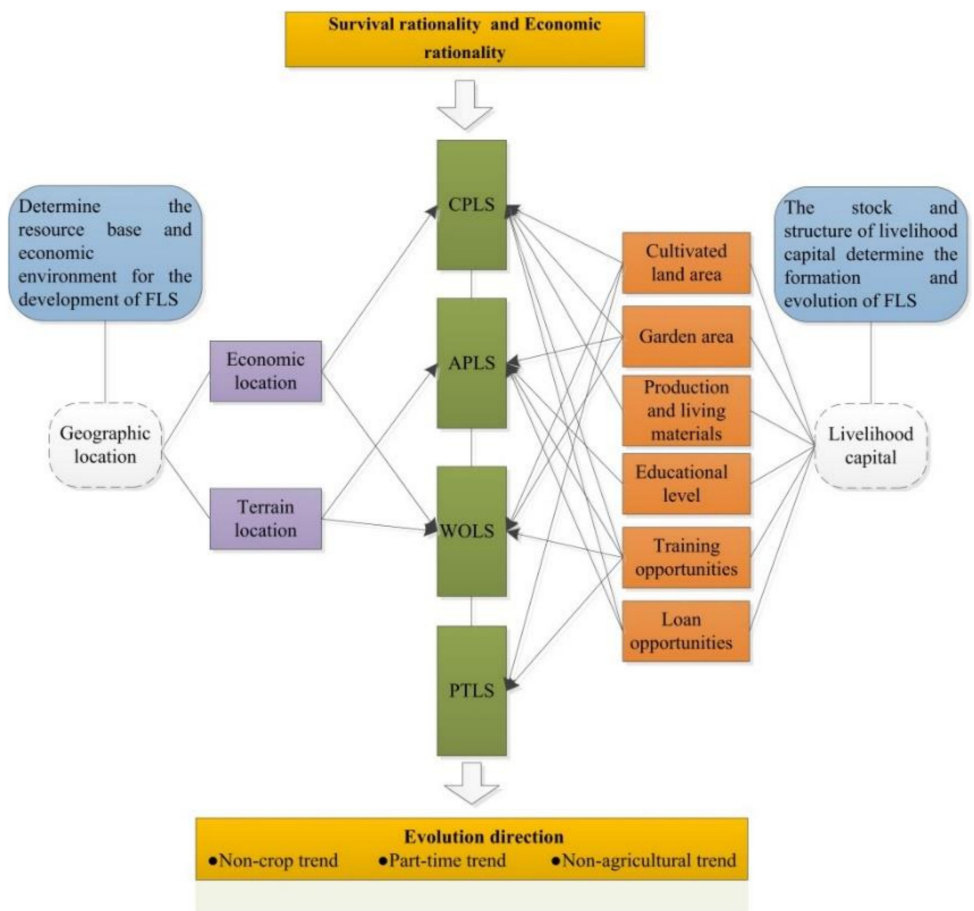

Figure 8. Mechanism of the factors influencing FLS evolution. 


\section{Discussion}

\subsection{The Role of Geographic Location in the Evolution of FLS}

In the early 1980s, FLS were mainly focused on crop cultivation. During the process of industrialization and urbanization in the economic core region of Changwu County, a large amount of cultivated land was expropriated in the rural region, resulting in a decline in regional agricultural production potential. In addition, the superior regional nonagricultural employment conditions led to a large inflow of rural labor into non-agricultural livelihood activities. These developments caused FLS to evolve from the CPLS to the WOLS. Compared to the economic core region, due to the better agricultural production conditions in the economic fringe region, the evolution of the dominant livelihood strategies among farmers was a progressive process of CPLS to APLS to WOLS based on the full use of agricultural resources.

As the photothermal conditions in the loess tableland region are ideal for apple cultivation, the quality of the apples produced in this region is better, allowing them to be sold at higher market prices than those produced in other regions. As a result, apple growing became the dominant livelihood activity in the loess tableland region for a period. In contrast, the loess gully region and loess ridge region are not suitable for apple cultivation, making it unlikely to be the dominant livelihood activity of farmers there. In addition, agricultural productivity is low in the loess ridge region and loess gully region because of the poor quality of cultivated land, which has forced an increasing number of rural laborers to work in non-agricultural sectors. Therefore, the regions followed the jump evolution path and entered the non-agricultural phase earlier.

\subsection{The Role of Livelihood Capital in the Evolution of FLS}

(1) Training opportunities were the key variable of FLS differentiation in the early period.

In the early period of the reform and opening up, the rural livelihood activities in Changwu County were dominated by traditional crop cultivation. With the introduction of apple cultivation technology and the popularization of technical training provided by government organizations, some farmers who had mastered apple-cultivation technology abandoned crop cultivation. As the extent of apple growing continued to expand, the APLS emerged, and FLS started to diverge. With the continuous development of productivity, training opportunities continued to play an important role in the differentiation and development of FLS, with a significantly positive effect on the APLS and a significantly negative effect on the formation and development of the remaining three livelihood strategies.

(2) Cultivated land area and garden area, as forms of natural capital, played an important role in promoting and maintaining the CPLS and the APLS.

With the development of productivity levels, traditional crop cultivation was gradually replaced by livelihood activities such as non-agricultural work and apple growing. However, some farmers with extensive cultivated land still actively improved on methods for traditional crop cultivation, thereby maintaining the existence and development of the CPLS. In addition, with the promotion and popularization of apple cultivation technology, the impact of technical training on the APLS gradually weakened, and garden area gradually became a key variable affecting the development of the APLS. The garden is the land foundation for apple cultivation. Therefore, farmers with more garden area were more likely to use it for apple planting, which in turn promoted the formation and development of the APLS.

(3) Natural capital and training opportunities hindered the formation and development of the WOLS.

The previous analysis showed that the WOLS first appeared in the economic core region and loess gully region. The better non-agricultural production conditions in the economic core region and the poor agricultural production environment in the loess gully region led farmers to break away from agricultural production early and engage in the WOLS. However, cultivated land area, garden area, and training opportunities promoted 
and maintained the CPLS and APLS, which, in turn, hindered the formation and development of the WOLS.

(4) Impact of other livelihood capital variables on the evolution of livelihood strategies.

Diversified production and living materials are prerequisites for non-agricultural livelihood activities. Therefore, farmers with more production and living materials are more likely to form PTLS. In addition, with the development of the apple industry, the government gradually stopped the distribution of free materials to growers. However, in apple cultivation, there is a lag between planting and deriving income, so the purchase of agricultural materials in the early stage of apple planting needs a substantial amount of money to be maintained. To a certain extent, the greater the number of people who can loan money, the better the farmers' ability to raise funds is, resulting in financial guarantees for apple cultivation, further promoting the formation and development of the APLS.

\subsection{Comparative Analysis with Existing Research Results}

The results of this study have certain similarities with the existing related research results on the Loess Plateau. In terms of the impact of geographic location on FLS, through the comparative analysis of FLS in different terrain regions on the Loess Plateau, Lu et al., pointed out that the fruit-planting livelihood strategy is mainly distributed in the loess tableland region, while the non-agricultural livelihood strategy is mainly distributed in the loess gully region [61], which is almost consistent with the results on the distribution of FLS in our study. The difference is that Lu et al., ignored the role of economic location. In terms of the overall development trend of FLS, some existing research results show that the project of returning farmland to forests, as well as urbanization and industrialization, has shifted the development of FLS towards the direction of the fruit industry and nonagricultural activities on the Loess Plateau [62-64]. Our research results on the evolution of FLS are not only consistent with the existing results in the direction of evolution, but also analyzed the specific process of the evolution of FLS. In addition, in their research on the differentiation of FLS on the Loess Plateau, Wang et al., also concluded that social capital plays an important role in the formation of fruit farmers [65], which further supports the relevant results of our study. In summary, the results of the case study reflect the actual development of FLS on the Loess Plateau to a certain extent, and the analytical framework is applicable to the study on the FLS on the Loess Plateau.

From related studies in other regions, the research results of Wamalwa et al., show that the effect of human capital, physical capital, financial capital, natural capital, and social capital is determined by forest, crop, livestock, and off-farm activities in Kieni Sub Counties, Kenya [66]. Baruah et al., revealed that the training of aquaculture technology is of great significance to the development of the livelihood strategy of fish farming in the high altitude areas of Arunachal Pradesh [67]. Through a comparative analysis of the differences in the livelihood choice of tea industry by farmers at different altitudes in the Himalayas, Jairu et al., concluded that terrain location has an important impact on the participation of FLS in the tea industry [68]. Due to differences in regional resource endowment, productivity levels, and policy systems, etc., the FLS in the above study areas were different from those on the Loess Plateau. However, these research results still show that geographic location and livelihood capital have an important impact on the FLS. It can be seen that the analytical framework designed in the current study still has certain applicability in other regions.

From the research sample, the farmers surveyed are involved in different terrain locations and different economic locations. The livelihood activities of the farmers include traditional agricultural production, fruit production, and non-agricultural production mainly based on going out to work. According to the participation in these livelihood activities, four types of livelihood strategies are formed, including CPLS, APLS, WOLS, and PTLS. This is in considerable agreement with the relevant research results on the Loess Plateau $[61,62,65]$. In addition, with the development of productivity and changes in the global environment, the FLS in many developing countries and regions have gradually 
shifted towards a non-agricultural direction [69-72]. It can be seen that due to the disparity in the outcome benefits of different industries, when the level of productivity develops to a certain extent, the non-agricultural transfer of FLS is inevitable. Therefore, although there will be differences in specific livelihood strategies, our sample is highly representative of the overall direction of the evolution of livelihood strategies. This also shows that the analytical framework has certain applicability to other regions.

\subsection{Policy Implications}

Breaking the limitation of geographic location on FLS is of considerable significance to promote the sustainable development of farmers' livelihoods. Therefore, it is necessary to strengthen the construction of regional infrastructure for regional rural development, especially on the Loess Plateau. To date, China has implemented many rural development strategies and measures (beautiful villages, rural vitalization strategies, village-to-village projects, immigration relocation, targeted poverty reduction strategies, etc.) to promote the healthy development of farmers' livelihoods, and has achieved tremendous results. These strategic guidelines not only improve the rural social development environment, but also promote the development of the rural economy through the restructuring of rural industries and the integration of resources, as they provide experience and a reference for rural development and the development of farmers' livelihoods in developing countries.

Furthermore, to achieve rural revitalization and development, the Chinese government must attach importance to building up livelihood capital and promptly optimize the structure of livelihood capital for farmers on the Loess Plateau. First, the education department and human resources department should improve the adult education system and production skills training system for farmers, and carry out re-education to expand farmers employment opportunities as well as periodic training on production skills to promote the knowledge-based and energy-saving transformation of farmers' human capital. Second, the financial sector and financial system should improve regional microfinance credit projects and agricultural and non-agricultural special credit projects to strengthen financial support for the development of rural farmers' livelihoods. Finally, local government departments should build online information platforms to promote the diversified development of farmers' information acquisition channels and enhance farmers' understanding of agricultural market information, employment information, and national policy information.

\subsection{Limitations of the Study and Future Research}

There are still some insufficiencies in this study that need to be improved. In this study, economic location and terrain location were used as geographic location variables to identify the influencing factors of FLS evolution. The geographic location indicators selected are not meticulous enough, resulting in the need for the accuracy of the influencing factor identification result to be further improved. Therefore, an effective way to improve the accuracy of the research results is through selecting more detailed geographic location indicators such as altitude, slope, traffic accessibility, and market location to analyze the influencing factors of the evolution of FLS. In addition, the analytical framework still has room for expansion in terms of influencing factor selection and research content. This is an area that is currently being worked on, and this will continue in order to incorporate more detailed influencing factors from multiple aspects, and to explore the comprehensive impact of the interactions among influencing factors on the evolution and development of FLS. Moreover, in the context of drastic changes in the global environment, the development of FLS is affected by many factors, such as climate change, policy changes, and production technology innovations. Therefore, combining the actual situation of regional development and exploring the development of FLS from the perspective of multiple factors is an important direction to promote relevant research and achieve breakthroughs. 


\section{Conclusions}

This study shows that the evolution of FLS in the study area has obvious non-crop and non-agricultural directions. Geographic location and livelihood capital have a significant impact on the evolution of FLS. Differences in economic location and terrain location lead to differences in the resource endowment and industrial environment for regional livelihood development, which, in turn, makes the evolution of FLS in different economic sub-regions and terrain sub-regions follow two different evolution paths: the progressive path, and the jump path. The difference in livelihood capital leads to the differentiation of FLS options, which, in turn, promotes the dynamic evolution of FLS. Natural capital still has an important influence on the evolution of FLS, and is the basis for the development of CPLS and APLS. Social capital and financial capital play an important supporting role in the formation and development of APLS. Conversely, a lack of natural capital and social capital shifts FLS towards the direction of non-agricultural work. The results of the case study are representative the development of FLS and reflect the characteristics of trends in the development of FLS on the Loess Plateau. The analytical framework is applicable to the Loess Plateau and other regions to a certain extent.

Author Contributions: Conceptualization, K.W. and X.Y.; Methodology, K.W.; Data Curation, K.W.; Software, J.Z.; Writing-Original draft preparation, K.W.; Writing-Reviewing and Editing, J.Z. and Z.W.; Supervision, X.Y. All authors have read and agreed to the published version of the manuscript.

Funding: This study was supported by the National Natural Science Foundation of China (No. 41771574).

Institutional Review Board Statement: Not applicable.

Informed Consent Statement: Not applicable.

Data Availability Statement: The data presented in this study are available on request from the corresponding author.

Acknowledgments: We would like to thank Sha Yin, Jianghao Ma, Feng Hu, Wenwei Han, and Wenli Ye for contributing to the household survey and data collection. Furthermore, the authors would like to express their appreciation to the anonymous reviewers for the insightful comments that improved this manuscript.

Conflicts of Interest: The authors declare no conflict of interest. 


\section{Appendix A}

Table A1. The general situation of farmers' livelihood capital in different periods

\begin{tabular}{|c|c|c|c|c|c|c|c|c|c|c|c|c|c|c|}
\hline \multirow{2}{*}{ Period } & \multirow{2}{*}{ Livelihood Capital } & \multirow{2}{*}{ Index } & \multicolumn{4}{|c|}{ Loess Gully Region } & \multicolumn{4}{|c|}{ Loess Ridge Region } & \multicolumn{4}{|c|}{ Loess Tableland Region } \\
\hline & & & Max & Min & Mean & Std & Max & Min & Mean & Std & Max & Min & Mean & Std \\
\hline \multirow{9}{*}{2018} & Nature capital & Cultivated land area & 8.50 & 0.50 & 2.05 & 1.55 & 8.00 & 0.40 & 2.47 & 1.81 & 6.50 & 0.17 & 1.48 & 0.95 \\
\hline & \multirow{2}{*}{ Human capital } & Labor force & 100.00 & 0.00 & 73.88 & 28.80 & 100.00 & 0.00 & 75.08 & 26.27 & 100.00 & 0.00 & 70.75 & 23.16 \\
\hline & & Education level & 3.75 & 1.00 & 2.29 & 0.63 & 4.00 & 1.00 & 2.43 & 0.79 & 4.67 & 1.00 & 2.41 & 0.72 \\
\hline & Physical capital & $\begin{array}{l}\text { Production and } \\
\text { living materials }\end{array}$ & 10.00 & 1.00 & 5.20 & 1.85 & 9.00 & 2.00 & 6.26 & 1.57 & 10.00 & 1.00 & 6.08 & 1.91 \\
\hline & \multirow{2}{*}{ Financial capital } & Credit opportunities & 1.00 & 0.00 & 0.52 & 0.50 & 1.00 & 0.00 & 0.56 & 0.50 & 1.00 & 0.00 & 0.66 & 0.47 \\
\hline & & Loan opportunities & 10.00 & 0.00 & 3.75 & 2.61 & 13.00 & 0.00 & 4.13 & 2.89 & 10.00 & 0.00 & 3.99 & 2.38 \\
\hline & \multirow{3}{*}{ Social capital } & Social network & 1.00 & 0.00 & 0.10 & 0.30 & 1.00 & 0.00 & 0.13 & 0.34 & 1.00 & 0.00 & 0.17 & 0.38 \\
\hline & & Neighborhood trust & 1.00 & 0.00 & 0.71 & 0.23 & 1.00 & 0.25 & 0.80 & 0.16 & 1.00 & 0.00 & 0.74 & 0.22 \\
\hline & & $\begin{array}{c}\text { Training } \\
\text { opportunities }\end{array}$ & 5.00 & 0.00 & 0.63 & 1.04 & 4.00 & 0.00 & 0.62 & 0.94 & 8.00 & 0.00 & 1.49 & 1.58 \\
\hline \multirow{9}{*}{2010} & Nature capital & Garden area & 2.00 & 0.00 & 0.30 & 0.40 & 1.33 & 0.00 & 0.42 & 0.36 & 2.50 & 0.00 & 0.59 & 0.45 \\
\hline & \multirow{2}{*}{ Human capital } & Labor force & 100.00 & 25.00 & 67.24 & 24.03 & 100.00 & 20.00 & 66.73 & 21.15 & 100.00 & 0.00 & 64.92 & 21.65 \\
\hline & & Education level & 4.58 & 0.52 & 1.96 & 0.79 & 3.75 & 0.88 & 2.06 & 0.77 & 4.23 & 0.41 & 2.06 & 0.73 \\
\hline & Physical capital & $\begin{array}{l}\text { Production and } \\
\text { living materials }\end{array}$ & 9.00 & 0.00 & 3.37 & 1.71 & 6.00 & 1.00 & 3.62 & 1.35 & 8.00 & 1.00 & 3.69 & 1.48 \\
\hline & \multirow{2}{*}{ Financial capital } & Credit opportunities & 1.00 & 0.00 & 0.72 & 0.45 & 1.00 & 0.00 & 0.74 & 0.44 & 1.00 & 0.00 & 0.72 & 0.45 \\
\hline & & Loan opportunities & 10.00 & 0.00 & 3.77 & 2.55 & 13.00 & 0.00 & 3.62 & 2.57 & 10.00 & 0.00 & 3.79 & 2.32 \\
\hline & \multirow{3}{*}{ Social capital } & Social network & 1.00 & 0.00 & 0.10 & 0.30 & 1.00 & 0.00 & 0.10 & 0.31 & 1.00 & 0.00 & 0.16 & 0.37 \\
\hline & & Neighborhood trust & 1.00 & 0.00 & 0.73 & 0.20 & 1.00 & 0.25 & 0.78 & 0.20 & 1.00 & 0.00 & 0.75 & 0.21 \\
\hline & & $\begin{array}{c}\text { Training } \\
\text { opportunities }\end{array}$ & 2.00 & 0.00 & 0.52 & 0.79 & 5.00 & 0.00 & 0.56 & 1.12 & 6.00 & 0.00 & 1.00 & 1.21 \\
\hline
\end{tabular}


Table A1. Cont.

\begin{tabular}{|c|c|c|c|c|c|c|c|c|c|c|c|c|c|c|}
\hline \multirow{2}{*}{ Period } & \multirow{2}{*}{ Livelihood Capital } & \multirow{2}{*}{ Index } & \multicolumn{4}{|c|}{ Loess Gully Region } & \multicolumn{4}{|c|}{ Loess Ridge Region } & \multicolumn{4}{|c|}{ Loess Tableland Region } \\
\hline & & & Max & Min & Mean & Std & $\operatorname{Max}$ & Min & Mean & Std & $\operatorname{Max}$ & Min & Mean & Std \\
\hline \multirow{10}{*}{2000} & \multirow{2}{*}{ Nature capital } & Cultivated land area & 8.50 & 0.50 & 1.69 & 1.18 & 6.67 & 0.30 & 2.41 & 1.64 & 4.20 & 0.17 & 1.31 & 0.89 \\
\hline & & Garden area & 2.00 & 0.00 & 0.29 & 0.40 & 1.33 & 0.00 & 0.42 & 0.36 & 2.00 & 0.00 & 0.64 & 0.49 \\
\hline & \multirow{2}{*}{ Human capital } & Labor force & 100.00 & 25.00 & 67.38 & 23.71 & 100.00 & 20.00 & 66.73 & 21.15 & 100.00 & 33.33 & 62.49 & 23.05 \\
\hline & & Education level & 3.64 & 0.39 & 1.49 & 0.64 & 2.86 & 0.40 & 1.48 & 0.58 & 2.45 & 0.53 & 1.59 & 0.47 \\
\hline & Physical capital & $\begin{array}{l}\text { Production and } \\
\text { living materials }\end{array}$ & 7.00 & 0.00 & 2.52 & 1.31 & 6.00 & 0.00 & 2.69 & 1.36 & 5.00 & 1.00 & 2.62 & 0.82 \\
\hline & \multirow{2}{*}{ Financial capital } & Credit opportunities & 1.00 & 0.00 & 0.63 & 0.49 & 1.00 & 0.00 & 0.72 & 0.46 & 1.00 & 0.00 & 0.62 & 0.49 \\
\hline & & Loan opportunities & 8.00 & 0.00 & 3.65 & 2.22 & 13.00 & 0.00 & 3.62 & 2.51 & 10.00 & 1.00 & 3.65 & 1.91 \\
\hline & \multirow{3}{*}{ Social capital } & Social network & 1.00 & 0.00 & 0.10 & 0.30 & 1.00 & 0.00 & 0.08 & 0.27 & 1.00 & 0.00 & 0.18 & 0.39 \\
\hline & & Neighborhood trust & 1.00 & 0.00 & 0.72 & 0.22 & 1.00 & 0.50 & 0.81 & 0.18 & 1.00 & 0.25 & 0.76 & 0.19 \\
\hline & & $\begin{array}{c}\text { Training } \\
\text { opportunities }\end{array}$ & 2.00 & 0.00 & 0.42 & 0.77 & 5.00 & 0.00 & 0.56 & 0.99 & 3.00 & 0.00 & 0.62 & 0.95 \\
\hline \multirow{9}{*}{1990} & Nature capital & Garden area & 2.00 & 0.00 & 0.31 & 0.41 & 1.50 & 0.00 & 0.47 & 0.43 & 2.50 & 0.00 & 0.61 & 0.47 \\
\hline & \multirow{2}{*}{ Human capital } & Labor force & 100.00 & 25.00 & 66.87 & 24.07 & 100.00 & 25.00 & 68.47 & 23.19 & 100.00 & 0.00 & 62.57 & 22.13 \\
\hline & & Education level & 3.00 & 0.20 & 1.21 & 0.51 & 2.50 & 0.67 & 1.42 & 0.50 & 6.33 & 0.25 & 1.41 & 0.65 \\
\hline & Physical capital & $\begin{array}{l}\text { Production and } \\
\text { living materials }\end{array}$ & 4.00 & 0.00 & 1.52 & 0.95 & 4.00 & 0.00 & 1.69 & 0.83 & 4.00 & 0.00 & 1.65 & 0.88 \\
\hline & \multirow{2}{*}{ Financial capital } & Credit opportunities & 1.00 & 0.00 & 0.47 & 0.50 & 1.00 & 0.00 & 0.67 & 0.48 & 1.00 & 0.00 & 0.57 & 0.50 \\
\hline & & Loan opportunities & 10.00 & 0.00 & 3.25 & 2.45 & 13.00 & 0.00 & 2.67 & 2.59 & 10.00 & 0.00 & 2.96 & 2.50 \\
\hline & \multirow{3}{*}{ Social capital } & Social network & 1.00 & 0.00 & 0.03 & 0.18 & 1.00 & 0.00 & 0.08 & 0.27 & 1.00 & 0.00 & 0.13 & 0.33 \\
\hline & & Neighborhood trust & 1.00 & 0.00 & 0.75 & 0.21 & 1.00 & 0.25 & 0.79 & 0.18 & 1.00 & 0.00 & 0.76 & 0.21 \\
\hline & & $\begin{array}{c}\text { Training } \\
\text { opportunities }\end{array}$ & 2.00 & 0.00 & 0.32 & 0.70 & 2.00 & 0.00 & 0.21 & 0.47 & 5.00 & 0.00 & 0.54 & 0.96 \\
\hline
\end{tabular}


Table A2. The overall fitting effect of binary logistic regression.

\begin{tabular}{ccccc}
\hline $\begin{array}{c}\text { Livelihood Strategy } \\
\text { Type }\end{array}$ & Period & $\begin{array}{c}\text { Model } \\
\text { Chi-Square }\end{array}$ & $\begin{array}{c}\text { Model } \boldsymbol{p} \\
\text { Value }\end{array}$ & $\begin{array}{c}\text { Nagelkerke } \\
\text { R-Square }\end{array}$ \\
\hline $\begin{array}{c}\text { Crop-planting livelihood } \\
\text { strategy (CPLS) }\end{array}$ & 1990 & 39.133 & 0.000 & 0.258 \\
& 2000 & 41.341 & 0.000 & 0.308 \\
Apple-planting livelihood & 2018 & 22.124 & 0.036 & 0.383 \\
strategy (APLS) & 1990 & 39.133 & 0.000 & 0.298 \\
& 2000 & 59.016 & 0.000 & 0.305 \\
Work-oriented livelihood & 2010 & 63.063 & 0.000 & 0.331 \\
strategy (WOLS) & 2000 & 52.521 & 0.000 & 0.388 \\
\hline Part-time comprehensive & 2010 & 53.068 & 0.000 & 0.297 \\
livelihood strategy (PTLS) & 2018 & 54.074 & 0.000 & 0.277 \\
\hline
\end{tabular}

\section{References}

1. Chambers, R.; Conway, G.R. Sustainable Rural Livelihoods: Practical Concepts for the 21st Century; IDS Discussion Paper No. 296; Institute of Development Studies: Brighton, UK, 1992; Available online: https://opendocs.ids.ac.uk/opendocs/bitstream/ handle/20.500.12413/3390/Wp72.pdf?sequence=1\&isAllowed=y (accessed on 27 December 2021).

2. DFID. Sustainable Livelihoods Guidance Sheets; Department for International Development: London, UK, 2000.

3. Scoones, I. Sustainable Rural Livelihoods: A Framework for Analysis; IDS Working Paper 72; Institute of Development Studies: Brighton, UK, 1998; Available online: https:/ / www.researchgate.net/publication/251873585_Sustainable_Rural_Livelihoods_A_ Framework_for_Analysis (accessed on 27 December 2021).

4. Daovisan, H.; Promphakping, B.; Chamaratana, T. Selling labor-domain livelihood assets: A qualitative approach to nonsubcontracting home-based garment workers in the Lao PDR. Kasetsart J. Soc. Sci. 2019, 40, 459-465. [CrossRef]

5. Gerlitz, J.Y.; Macchi, M.; Brooks, N.; Pandey, R.; Banerjee, P.; Jha, S.K. The multidimensional livelihood vulnerability index-An instrument to measure livelihood vulnerability to change in the hindu kush Himalayas. Clim. Dev. 2017, 9, 124-140. [CrossRef]

6. Jampel, C. Cattle-based livelihoods, changes in the taskscape, and human-bear conflict in the Ecuadorian Andes. Geoforum 2016, 69, 84-93. [CrossRef]

7. Oberlack, C.; Tejada, L.; Messerli, P.; Rist, S.; Giger, M. Sustainable livelihoods in the global land rush? Archetypes of livelihood vulnerability and sustainability potentials. Glob. Environ. Change 2016, 41, 153-171. [CrossRef]

8. $\quad$ Singh, R.K.; Zander, K.K.; Kumar, S.; Singh, A.; Sheoran, P.; Kumar, A.; Hussain, S.M.; Riba, T.; Rallen, O.; Lego, Y.J.; et al Perceptions of climate variability and livelihood adaptations relating to gender and wealth among the Adi community of the Eastern Indian Himalayas. Appl. Geogr. 2017, 86, 41-52. [CrossRef]

9. Babulo, B.; Muys, B.; Nega, F.; Tollens, E.; Nyssen, J.; Deckers, J.; Mathijs, E. Household livelihood strategies and forest dependence in the highlands of Tigray, Northern Ethiopia. Agric. Syst. 2008, 98, 147-155. [CrossRef]

10. Dovie, B.D.K.; Witkowskia, E.T.F.; Shackleton, C. Direct-use value of smallholder crop production in a semi-arid rural South African village. Agric. Syst. 2003, 76, 337-357. [CrossRef]

11. Steenbergen, D.J.; Marlessy, C.; Holle, E. Effects of rapid livelihood transitions: Examining local co-developed change following a seaweed farming boom. Mar. Policy 2017, 82, 216-223. [CrossRef]

12. Barrett, C.B.; Reardon, T.; Webb, P. Nonfarm income diversification and household livelihood strategies in rural Africa: Concepts, dynamics, and policy implications. Food Policy 2001, 26, 315-331. [CrossRef]

13. Ellis, F. Household strategies and rural livelihood diversification. J. Dev. Stud. 1998, 35, 1-38. [CrossRef]

14. Olusola, A.A.; Adenegan, K.O. Rural livelihood in south-west Nigeria: Strategies, assets ownerships and the non-farm income. Res. J. Appl. Sci. 2012, 6, 344-348. [CrossRef]

15. Jiao, X.; Pouliot, M.; Walelign, S.Z. Livelihood Strategies and Dynamics in Rural Cambodia. World Dev. 2017, 97, 266-278. [CrossRef]

16. Adepoju, A.O.; Obayelu, O.A. Livelihood diversification and welfare of rural households in Ondo State, Nigeria. J. Dev. Agric. Econ. 2013, 5, 482-489. [CrossRef]

17. Khatiwada, S.P.; Deng, W.; Paudel, B.; Khatiwada, J.R.; Zhang, J.F.; Su, Y. Household livelihood strategies and implication for poverty reduction in rural areas of central Nepal. Sustainability 2017, 9, 612. [CrossRef]

18. Mengistu, D.; Haji, J. Factors affecting the choices of coping strategies for climate extremes: The case of Yabello District, Borana Zone, Oromia National Regional State, Ethiopia. Sci. Res. 2015, 3, 129-136. [CrossRef]

19. Robaa, B.; Tolossa, D. Rural livelihood diversification and its effects on household food security: A case study at Damota Gale Woreda, Wolayta, Southern Ethiopia. East. Afr. Soc. Sci. Res. Rev. 2016, 32, 93-118. [CrossRef] 
20. Siraj, M.; Khan, H. Impact of micro hydropower projects on household income, expenditure and diversification of livelihood strategies in Azad Jammu and Kashmir. Pak. Dev. Rev. 2019, 58, 45-63. [CrossRef]

21. Ho, T.D.N.; Tsusaka, T.W.; Kuwornu, J.K.M.; Datta, A.; Nguyen, L.T. Do rice varieties matter? Climate change adaptation and livelihood diversification among rural smallholder households in the Mekong Delta region of Vietnam. Mitig. Adapt. Strateg. Glob. Change 2022, 27, 8. [CrossRef]

22. Nambeye, E.; Mubanga, K.H. The Failure of Common Farming Systems in Promoting Livelihood Diversification and Food Sufficiency among Smallholder Farmers: Evidence from Choma, Zambia. In Opportunities and Challenges of Smallholders and Smallholding; Nova Science Publishers, Inc.: New York, NY, USA, 2021; pp. 183-214.

23. Tukela, B.; Rao, C.A.; Rambabu, K. Analysis of Livelihood Diversification Practice on Reduction of Rural Poverty: The Case of Hawassa Zuria Woreda of Sidama Region, Ethiopia. Int. J. All Res. Educ. Sci. Methods 2021, 9, 799-808.

24. Siqin, C.K.T.; Fang, Y.G.; Wang, H.; Xu, K. Household-livelihood Assets and Strategies in Farming-pastoral Region: The Case of Shuangyushu Gaqa, Inner Mongolia. Sci. Geogr. Sin. 2017, 37, 1095-1103. (In Chinese) [CrossRef]

25. Walelign, S.Z. Livelihood strategies, environmental dependency and rural poverty: The case of two villages in rural Mozambique. Environ. Dev. Sustain. 2016, 18, 593-613. [CrossRef]

26. Chand, R. Labour migration as a livelihood strategy in far east Bhutan: A case study of a marginal Bhutanese Community. Hrvat. Geogr. Glas. 2014, 75, 41-57. [CrossRef]

27. Martina, R.; Linstadter, A.; Frank, K.; Müller, B. Livelihood security in face of drought-Assessing the vulnerability of pastoral households. Environ. Model. Softw. 2016, 75, 414-423. [CrossRef]

28. Olsen, C.S.; Larsen, H.O. Alpine medicinal plant trade and Himalayan mountain livelihood strategies. Geogr. J. 2003, 169, 243-254 [CrossRef]

29. Oostenbrugge, J.A.E.V.; Densen, W.L.T.V.; Machiels, M.A.M. How the uncertain outcomes associated with aquatic and land resource use affect livelihood strategies in coastal communities in the Central Moluccas, Indonesia. Agric. Syst. 2004, 82, 57-91. [CrossRef]

30. Qian, C.; Sasaki, N.; Jourdain, D.; Kim, S.M.; Shivakoti, P.G. Local livelihood under different governances of tourism development in China-A case study of Huangshan mountain area. Tour. Manag. 2017, 61, 221-233. [CrossRef]

31. Toillier, A.; Serpantié, G.; Hervé, D.; Lardon, S. Livelihood strategies and land use changes in response to conservation: Pitfalls of community-based forest management in Madagascar. J. Sustain. For. 2011, 30, 20-56. [CrossRef]

32. Chibinga, O.; Musimba, M.; Nyangito, M.; Simbaya, J.; Moses, D. Climate Variability impact on Livelihood Strategies among Agro-Pastoralists in Southern Zambia. Agriculture 2021, 1, 25-29.

33. Tesfaye, Y.; Roos, A.; Campbell, B.M.; Bohlin, F. Livelihood strategies and the role of forest income in participatory-managed forests of Dodola area in the bale highlands, southern Ethiopia. For. Policy Econ. 2011, 13, 258-265. [CrossRef]

34. Raihan, F.; Milon, M. Livelihood vulnerability assessments and adaptation strategies to climate change: A case study in Tanguar haor, Sylhet. J. Water Clim. Change 2021, 12, 3448-3463. [CrossRef]

35. Mulatie, C.; Timkete, A. Internal migration, rural livelihood strategies and sustainable forest management: Evidence from Bench Maji, Kaffa and Sheka Zones, South West Ethiopia. Environ. Socio-Econ. Stud. 2021, 9, 20-31. [CrossRef]

36. Tang, Q.; Bennett, S.J.; Xu, Y.; Li, Y. Agricultural practices and sustainable livelihoods: Rural transformation within the Loess Plateau, China. Appl. Geogr. 2013, 41, 15-23. [CrossRef]

37. Sun, Z.; Zhao, L.; Wang, S.Y.; Zhang, H.Y.; Wang, X.Y.; Wan, Z.Y. Targeted Poverty Alleviation and Households' Livelihood Strategy in a Relation-Based Society: Evidence from Northeast China. Int. J. Environ. Res. Public Health 2021, 18, 1747. [CrossRef] [PubMed]

38. Mondal, M.R. Tourism as a livelihood development strategy: A study of Tarapith Temple Town, West Bengal. Asia-Pac. J. Reg. Sci. 2020, 4, 795-807. [CrossRef]

39. Chen, J.; Yin, S.; Gebhard, H.; Yang, X.J. Farmers' livelihood adaptation to environmental change in an arid region: A case study of the Minqin Oasis, northwestern China. Ecol. Indic. 2018, 93, 411-423. [CrossRef]

40. Fang, Y.P.; Fan, J.; Shen, M.Y.; Song, M.Q. Sensitivity of livelihood strategy to livelihood capital in mountain areas: Empirical analysis based on different settlements in the upper reaches of the Minjiang River, China. Ecol. Indic. 2014, 38, 225-235. [CrossRef]

41. Zhao, X.Y.; Liu, J.H.; Wang, W.J.; Lan, H.X.; Ma, P.Y.; Du, Y.X. Livelihood sustainability and livelihood intervention of out-ofpoverty farming households in poor mountainous areas: A case of Longnan mountainous area. Prog. Geogr. 2020, 39, $982-995$. (In Chinese) [CrossRef]

42. Mutabazi, K.D.; Amjath-Babu, T.S.; Sieber, S. Influence of livelihood resources on adaptive strategies to enhance climatic resilience of farm households in Morogoro, Tanzania: An indicator-based analysis. Reg. Environ. Change 2015, 15, 1259-1268. [CrossRef]

43. Salimah, N.; Muflikhati, I. Family capitals, livelihood strategies, and family well-being of plantation worker. J. Fam. Sci. 2016, 1, 13-23. [CrossRef]

44. Bebbington, A. Capitals and capabilities: A framework for analyzing peasant viability, rural livelihoods and poverty. World Dev. 1999, 27, 2021-2044. [CrossRef]

45. Koczberski, G.; Curry, G.N. Making a living: Land pressures and changing livelihood strategies among oil palm settlers in Papua New Guinea. Agric. Syst. 2005, 85, 324-339. [CrossRef]

46. Khosla, S.; Jena, P.R. Switch in livelihood strategies and social capital have a role to play in deciding rural poverty dynamics: Evidence from panel data analysis from Eastern India. J. Asian Afr. Stud. 2020, 55, 76-94. [CrossRef] 
47. Kuang, F.Y.; Jin, J.J.; He, R.; Wan, X.Y.; Ning, J. Influence of livelihood capital on adaptation strategies: Evidence from rural households in Wushen Banner, China. Land Use Policy 2019, 89, 104228. [CrossRef]

48. Longpichai, O.; Perret, S.R.; Shivakoti, G.P. Role of livelihood capital in shaping the farming strategies and outcomes of smallholder rubber producers in southern thailand. Outlook Agric. 2012, 41, 117-124. [CrossRef]

49. Rakodi, C. A capital assets framework for analysing household livelihood strategies: Implications for policy. Dev. Policy Rev. 1999, 17, 315. [CrossRef]

50. Yuliati, Y.; Isaskar, R. Social capital and sustainable livelihood strategies in downstream area of Bengawan Solo River, East Java, Indonesia. J. Sustain. Sci. Manag. 2018, 13, 201-209.

51. He, R.W.; Fang, F.; Liu, Y.W. Influence of human capital on the livelihood strategy of farming households in poor mountainous areas: A case study of Liangshan Yi Autonomous Prefecture of Sichuan. China. Prog. Geogr. 2019, 38, 1282-1293. [CrossRef]

52. Adam, Y.O.; Pretzsch, J.; Pettenella, D. Contribution of Non-Timber Forest Products livelihood strategies to rural development in drylands of Sudan: Potentials and failures. Agric. Syst. 2013, 117, 90-97. [CrossRef]

53. Nath, S.; Laerhoven, F.V.; Driessen, P.; Nadiruzzaman, M. Capital, rules or conflict? Factors affecting livelihood-strategies, infrastructure-resilience, and livelihood-vulnerability in the polders of Bangladesh. Sustain. Sci. 2020, 15, 1169-1183. [CrossRef]

54. Malherbe, W.; Sauer, W.; Aswani, S. Social capital reduces vulnerability in rural coastal communities of Solomon Islands. Ocean Coast. Manag. 2020, 191, 105186. [CrossRef]

55. Li, M.P.; Huo, X.X.; Peng, C.H.; Qiu, H.G.; Shangguan, Z.P.; Chang, C.; Huai, J. Complementary livelihood capital as a means to enhance adaptive capacity: A case of the Loess Plateau, China. Glob. Environ. Change 2017, 47, 143-152. [CrossRef]

56. Nolan, S.; Unkovich, M.; Shen, Y.Y.; Li, L.L.; Bellotti, W. Farming systems of the Loess Plateau, Gansu Province, China. Agric. Ecosyst. Environ. 2008, 124, 13-23. [CrossRef]

57. Wu, B.; Parnwell, M.; Bradley, P. Farmer self-organizing innovation in the marginal areas of China: A study of farmer communication networks in Zhidan, Loess Plateau. J. Rural Coop. 2002, 30, 43-63. [CrossRef]

58. Zhen, N.H.; Fu, B.J.; Lü, Y.H.; Zheng, Z.M. Changes of livelihood due to land use shifts: A case study of Yanchang County in the Loess Plateau of China. Land Use Policy 2014, 40, 28-35. [CrossRef]

59. Frankenberger, T.R.; Drinkwate, M.; Maxwell, D. Operational Household Livelihood Security: A Holistic Approach for Addressing Poverty and Vulnerability. 2000. Available online: http://mkatherinemccaston.com/PDF/operationalizing_household_ livelihood_security.pdf (accessed on 27 December 2021).

60. Krantz, L. The Sustainable Livelihood Approach to Poverty Reduction; Swedish International Development Cooperation Agency: Stockholm, Sweden, 2001; pp. 42-98.

61. Lu, D.M.; Yang, X.J.; Shi, Y.Z.; Wang, Z.Q. Rural regime shifts and transformation development on the Loess Plateau. Acta Geogr. Sin. 2020, 75, 348-364. (In Chinese) [CrossRef]

62. Yang, Q.Q.; Yang, X.J.; Gao, Y.H. Change in vulnerability of rural human settlement in the semi-arid area of the Loess Plateau since 1980: A case study of Jiaxian County, Shaanxi Province. Prog. Geogr. 2019, 38, 756-771. (In Chinese) [CrossRef]

63. Guo, B.; Xie, T.; Subrahmanyam, M.V. The impact of china's grain for green program on rural economy and precipitation: A case study of yan river basin in the loess plateau. Sustainability 2019, 11, 5336. [CrossRef]

64. Zhang, B.; Wu, P.; Zhao, X.; Gao, X.; Shi, Y. Assessing the spatial and temporal variation of the rainwater harvesting potential (1971-2010) on the chinese loess plateau using the vic model. Hydrol. Process. 2014, 28, 534-544. [CrossRef]

65. Wang, Z.Q.; Shi, C.P.; Jiang, W.; Yang, X.J. Rural transformation from the perspective of regime shifts of socio-ecological systems in the Loess Plateau: A case study of Hongjia town in Changwu county, China. Geogr. Res. 2016, 35, 1510-1524. (In Chinese) [CrossRef]

66. Wamalwa, F.; Ondieki-Mwaura, F.; Ayuke, F. The Influence of Household Assets on Livelihood Choices in Kieni Sub Counties, Kenya. Int. J. Soc. Sci. Humanit. Res. 2021, 6, 20-31.

67. Baruah, D.; Singh, N.D. Methodologies for Livelihood Support through Fish Farming at High Altitudes of Arunachal Pradesh. J. Krishi Vigyan 2017, 5, 108-115. [CrossRef]

68. Jairu, D.; Acharya, S.K. Impact of Altitude on the Livelihood of the Tea Garden Workers of North Bengal. Asian J. Agric. Ext. Econ. Sociol. 2020, 38, 34-44. [CrossRef]

69. Bonye, S.Z.; Aasoglenang, T.A.; Yiridomoh, G.Y. Urbanization, agricultural land use change and livelihood adaptation strategies in peri-urban Wa, Ghana Background to the study. SN Soc. Sci. 2021, 1, 9. [CrossRef]

70. Kehinde, A.L.; Alao, O.T.; Busari, A.O.; Oyaromade, R. Climate Change, Cost of Providing Water and Livelihood Diversification by Arable Crop Farmers in Nigeria. Niger. J. Agric. Econ. 2020, 10, 92-108. [CrossRef]

71. Boncinelli, F.; Bartolini, F.; Casini, L.; Brunori, G. On farm non-agricultural activities: Geographical determinants of diversification and intensification strategy. Lett. Spat. Resour. Sci. 2017, 10, 17-29. [CrossRef]

72. Lay, J.; Mahmoud, T.O.; M'Mukaria, G.M. Few Opportunities, Much Desperation: The Dichotomy of Non-Agricultural Activities and Inequality in Western Kenya. World Dev. 2008, 36, 2713-2732. [CrossRef] 